\title{
Slow axoplasmic transport under scrutiny
}

\author{
Felipe A. Court* and Jaime Álvarez
}

Faculty of Biological Sciences, P. Catholic University of Chile, Santiago, Chile, Millennium Nucleus for Regenerative Biology and Neurounion Biomedical Foundation, Santiago, Chile.

We dedicate this paper to Antonio Giuditta and Edward Koenig who laid the basis to understand the origin of axoplasmic protein.

\begin{abstract}
The origin of axoplasmic proteins is central for the biology of axons. For over fifty years axons have been considered unable to synthesize proteins and that cell bodies supply them with proteins by a slow transport mechanism. To allow for prolonged transport times, proteins were assumed to be stable, i.e., not degraded in axons. These are now textbook notions that configure the slow transport model (STM). The aim of this article is to cast doubts on the validity of STM, as a step toward gaining more understanding about the supply of axoplasmic proteins. First, the stability of axonal proteins claimed by STM has been disproved by experimental evidence. Moreover, the evidence for protein synthesis in axons indicates that the repertoire is extensive and the amount sizeable, which disproves the notion that axons are unable to synthesize proteins and that cell bodies supply most axonal proteins. In turn, axoplasmic protein synthesis gives rise to the metabolic model (MM). We point out a few inconsistencies in STM that MM redresses. Although both models address the supply of proteins to axons, so far they have had no crosstalk. Since proteins underlie every conceivable cellular function, it is necessary to re-evaluate indepth the origin of axonal proteins. We hope this will shape a novel understanding of the biology of axons, with impact on development and maintenance of axons, nerve repair, axonopathies and plasticity, to mention a few fields.
\end{abstract}

Key words: Protein synthesis, radioactive wave, maintenance of axons, Schwann cell, glia, transgenic mouse.

\section{OVERVIEW}

The most striking anatomical feature of neurons is the size and morphological variability of axons. Their sizes are impressive as they may attain enormous lengths and volumes, up to several thousands times those of the cell body. The terminals may be up to several meters away from the nucleus that holds the templates for proteins, raising logistical challenges. In this context, we make explicit the tenets of STM and examine their supporting evidence. In particular, we scrutinize the stability of axonal proteins and the inability of axons to synthesize proteins, and illustrate inconsistencies arising between this model and experimental data. We then put forth MM and offer an alternative explanation to the data considered so far to support transport. To discriminate between the two models, we propose experimental protocols. Finally, we suggest a new understanding of axon maintenance.

\section{The development of STM}

The textbook notion that most axoplasmic proteins originate in the cell body and are then conveyed down the axon at a slow rate (Schwartz and Camilli, 2000; Brady et al., 2008) was first proposed in the late forties based on ballooning proximal and thinning distal to nerve constrictions (Weiss and Hiscoe, 1948). Later, ribosomes were not reported in axons with electron microscopy, except close to the cell body (Palay et al., 1968; Peters et al., 1968; Zelená, 1972; Pannese and Ledda, 1991; Li et al., 2005b). Administration of labeled amino acids to cell bodies resulted in anterograde waves progressing at 1-2 mm/day, the label of which was embodied in axoplasmic proteins (Droz and Leblond, 1963). This result was replicated extensively, rendering wave and transport as synonymous. For a comprehensive review of this period, see Graftein and Forman (1980). Figure 1.A illustrates our case study of a wave moving away from the cell bodies.

Another wave of label was also observed that differed in various respects from the slow wave, firstly in that it was faster by two orders of magnitude (200-400 mm/day). It was associated with membranous organelles and was arrested by drugs that interfere with microtubules. Its destination was primarily the nerve terminals. The content accumulated at ligatures, and its progression depended on kinesin and dynein motor proteins (Mercer et al., 1994) and the actin filament-myosin filament pair (Bridgman, 2004). This is fast axonal transport. The amount of protein in the fast wave relative to that of the slow wave was small, as judged by the ratio between labels, and did not include significant axoskeletal proteins (McEwen and Grafstein, 1968; Karlsson and Sjöstrand, 1971; Droz et al., 1973); for reviews, see Graftein and Forman (1980) and Dahlstrom et al. (1992).

In the context of the supply of proteins to axons, the findings presented above were explicitly translated into the following notions (Lasek and Hoffman, 1976): (i) axons lack the machinery for protein synthesis; (ii) cell bodies synthesize most axonal proteins (iii) a transport mechanism is postulated to convey proteins; and finally, (iv) axoplasmic proteins are postulated to be stable in axons and eliminated at the terminals. That is, a column of proteins arising in the cell body is vectorially translocated down the axon $-\mathrm{a}$ biomechanical event- while synthesis and degradation of proteins -metabolic events- are explicitly excluded from axons. These tenets configured STM, in which the inability of axons to synthesize proteins is the central piece and tenets (ii), (iii) and (iv) are ancillary assumptions. Note that the stability of axoplasmic 
proteins for years or even decades, which STM has to postulate in order to be viable as a theory, is an implausible assumption with no precedent in other systems. The theoretical model is shown in Fig. 1.A' and its features are summarized in Table 1.

STM was soon accepted and remains unchanged and forms part of common knowledge up to this day. Thereafter, the study has focused on biomechanical events to explain protein translocation, which is still an unsettled issue. Many mechanisms have been proposed since the inception of STM over 60 years ago. Most of them have considered only cytoskeletal proteins instead of the full complement of axonal proteins, and none has gained general acceptance (Fig. 2) (for a discussion, see Miller and Heidemann, 2008). In recent years, translocation of discrete cytoskeletal assemblies has been clearly shown in axons of cultured neurons that move intermittently in either direction over short distances with an anterograde bias (Brown, 2000; Roy et al., 2000; Wang et al., 2000; Yuan et al., 2009). To be acceptable in the context of STM, these assemblies should not be just local rearrangements but must proceed from cell body to terminals in vivo. Alongside, cytoskeletal proteins, which are the most abundant, axons contain low amounts of over a hundred proteins, as shown by metabolic radiolabeling and 2D electrophoresis (Oblinger et al., 1987), which must also be supplied to axons. Moreover, the dynamics of these assemblies must explain the phenomenology pertaining to the field, such as radioactive waves, how proteins in terms of type and amount, are supplied to each segment, how they are regulated, how axons of any length arise, uniform but also presenting local anatomical changes either transient or permanent, assess the burden that the supply of axonal protein imposes upon the cell body, and so on. Briefly, STM is a great deal more than translocation of cytoskeletal proteins, as it has to explain the maintenance of the axon in all its complexity. Vectorial displacement of cytoskeletal proteins in axons of cultured neurons is an important, albeit initial step to understand the biological significance of protein translocation in axons (vide infra).

Scrutiny of protein stability in axons

Transport at $1-2 \mathrm{~mm} /$ day creates an outright conundrum. The travel time of proteins from the cell body to terminals will take several years in human axons and decades in those of larger species. If axonal proteins have usual life spans of days or weeks, they will disappear en route well before arriving to the terminals. To rescue STM from this inconsistency, axonal proteins were assumed to be stable without further ado (Weiss and Hiscoe, 1948; Lasek and Hoffman, 1976). However, circumstantial evidence challenged the notion of protein stability in axons. In efferent axons of the chick less than $15 \mathrm{~mm}$ long, over $90 \%$ of the radioactivity leaving cell bodies does not reach the terminals (Droz et al., 1973), i.e., proteins disappear in transit. The radioactivity of waves decreases consistently with time as they progress along the axon (Williard et al., 1974; Hoffman and Lasek, 1975; Cancalon, 1979; Mori et al., 1979), a fact clearly illustrated by our case study (Fig. 1, A). This loss of label indicates removal of protein from the axoplasm. Nixon (1980) addressed degradation of axonal proteins in optic nerves. Tracers were administered to the cell bodies and later the nerves were incubated to assess the amino acid release into the medium. The estimated half-life of proteins was about a week. However, the bearing of this finding on STM was not discussed. Briefly, protein degradation in axons has been unambiguously supported by metabolic studies, thus questioning the stability of proteins and in so doing, the consistency of STM as a construct.

With the advent of genetic engineering, degradation of proteins in axons was addressed again. Mice were generated to express the human neurofilament light subunit (hNFL+) and the transgene was under the negative control of a doxycyclineregulated promoter. Additionally, these hNFL+ mice either

TABLE

Overview of the maintenance of the axoplasm according to the slow transport model (STM) and the metabolic model (MM)

\begin{tabular}{|c|c|c|}
\hline & STM & MM \\
\hline Origin of axoplasmic proteins (bulk) & Cell body & Axoplasm \\
\hline Protein synthesis in axon & No & Yes \\
\hline Protein degradation in axon & No & Yes \\
\hline Life span of axonal proteins & Stable, even for years or decades & Usual \\
\hline Elimination of proteins in terminals & $\begin{array}{l}\text { Axonal proteins are lysed upon } \\
\text { reaching the terminals }\end{array}$ & Usual \\
\hline Slow long distance transport & Yes & No \\
\hline Transport mechanism & Required & No \\
\hline Protein supply to axons: a burden for cell bodies? & Expected & No \\
\hline $\begin{array}{l}\text { Regional anatomical variations caliber, } \\
\text { microtubules, etc }\end{array}$ & $\begin{array}{l}\text { Change in transport velocity of the } \\
\text { appropriate components }\end{array}$ & Local regulation of protein synthesis \\
\hline Response of axons to local challenges & Redistribution of existing proteins & Local synthesis or lysis of appropriate proteins \\
\hline $\begin{array}{l}\text { Proteins not belonging to the standard repertoire } \\
\text { are required at a distance from the cell body }\end{array}$ & $?$ & Local protein synthesis \\
\hline
\end{tabular}


expressed their own neurofilament light subunit (mNFL+) or did not (mNFL-) (Millecamps et al., 2007). In mice hNFL+/ mNFL- expressing only the human subunit, upon doxycycline treatment, the subunit disappeared at the same time along the entire sciatic nerve with a half-life of 3 weeks. Thus genetic engineering confirms classical metabolic studies that proteins are removed everywhere from the axon. Surprisingly, using the same protocol in the mouse that expresses both mouse and human NFL subunits, the human subunit declined to about $35 \%$ after eight months, which does not concur with the speedy decline when the mouse expresses hNFL alone. In dorsal root ganglia, the mRNA declined, but did not fully disappear, after two weeks of doxycycline treatment. Unfortunately, assessment of the mRNA level was discontinued in ganglia, and omitted altogether in the sciatic nerve. Since there is increasing evidence for axoplasmic synthesis of proteins and glia-toaxon transfer of RNA, a documented depletion of the mRNA coding hNFL in both ganglia and nerve would have added strong support to the long-term survival of hNFL protein. For its important theoretical implications, this finding deserves confirmation with an independent method, e.g, concurrent metabolic labeling of hNFL. Is long-term survival so reliable that it outweighs all other methods and all other estimates? Is it acceptable to extend the putative survival of a single foreign protein to all axoplasmic proteins without adequate experimental support? Even an unwarranted extension of this survival to the complete protein repertoire will not rescue long axons of humans, giraffes, or whales, as virtually no protein will reach their terminals either.

Miller and Samuels (1997), who included protein degradation in their simulation, assumed that the moving column was shorter precisely to maintain the packing of the axoplasmic components constant (Fig. 2, G). But data interpreted according to STM do not support this new assumption since the putative bolus of protein entering the axon, instead of shrinking, apreads out as it progresses (Fig. 1, A). Moreover, this assumption called for a complementary one, namely that axonal length determines the size of the bolus, i.e., the axoplasm should be a burden for the synthetic machinery of the cell body. However, experimental evidence indicates that protein synthesis in the cell body is unrelated to the axoplasmic mass (von Bernhardi and Alvarez, 1989), which indicates that axons are not a burden for cell bodies. This attempt to include protein degradation in STM did not succeed.

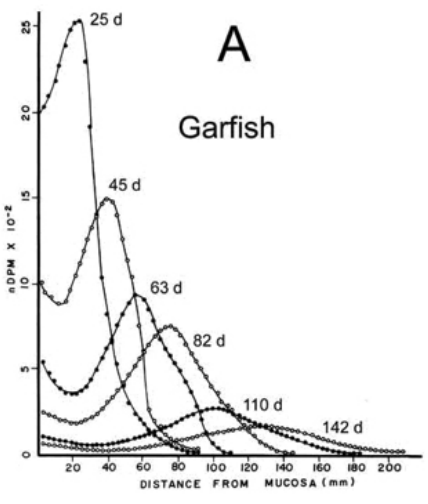

$A^{\prime}$

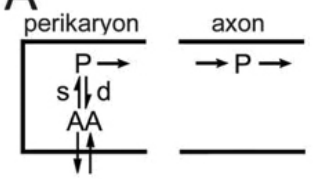

B

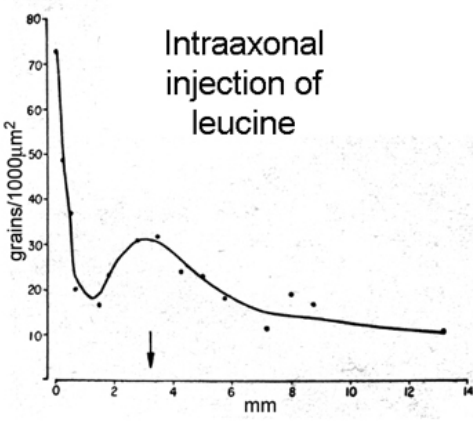

B'

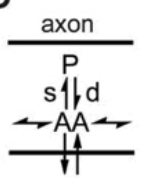

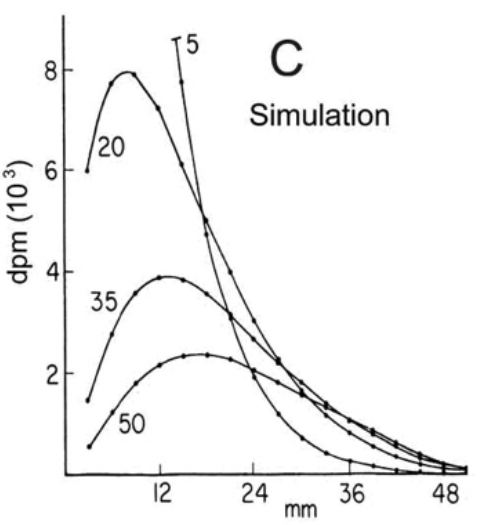

C'

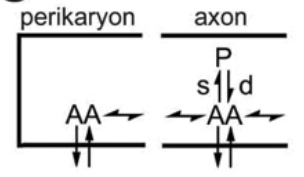

Figure 1. Radioactive waves in axons and explanatory models: Graphs $A, B$ and C: ordinates, radioactivity of axoplasmic proteins; abscissae, distance from cell body. Diagrams: $A^{\prime}$, slow transport model (STM), and $B^{\prime}$ and $C^{\prime}$, metabolic model (MM): $P$, protein; $\rightarrow$, vectorial translocation of $P ; A A$, amino acid; half arrows pointing up and down, synthesis and degradation of $P$, respectively; horizontal double arrows, axial diffusion, $\uparrow$ and $\downarrow$, uptake and leakage of AA. A, Garfish, olfactory cell bodies were administered pulses of tracers; each curve is the distribution of the label in the nerve proteins at the time indicated. The wave moves forward (from Cancalon, 1979; by permission of Wiley). Alternative description: each curve is the distribution in space of proteins of the age indicated and the protein content at each point is the sum of all curves, labeled and unlabeled. On inspection, distal regions have very little protein. $A^{\prime}$, events underlying $A$ according to STM; curves are boluses of proteins leaving the cell body that move down the axon and spread in the process. In STM, synthesis and degradation of proteins - metabolic events- do not occur in axons; and AA plays no role in the axoplasm. B, autoradiographic response of the axoplasm following an electrophoretic injection of $\mathrm{H}^{3}$-leucine $(\downarrow)$ into the Mauthner axon of the goldfish; the tracer was released using trains of pulses for one hour and after an additional half hour of rest the tissue was processed (from Álvarez and Chen, 1972). Notice the extensive spread of the label, the bell-shaped incorporation into axonal proteins and the efficient incorporation in the cell body $3.5 \mathrm{~mm}$ away from the site of injection. $B^{\prime}$, events underlying $B$ according to $M M$ : bidirectional diffusion of tracers and metabolic incorporation into proteins. C, computer simulation according to $M M$. Diffusion of $A A$, and synthesis and degradation of proteins are expressed as a set of differential equations; fifty axonal segments, each $1 \mathrm{~mm}$ long, are in a steady state. At time zero, a pulse of label is given to the cell body. Curves are the distribution of the label at the time indicated (from Álvarez and Torres, 1985; by permission of Elsevier). C', events underlying $C$ according to $M M$ : tracers diffuse from cell body to axon, are incorporated into axoplasmic proteins and upon their degradation, tracers are re-cycled. Note that in $\mathrm{MM}$, transport of protein --a biomechanical event- does not occur, nonetheless experimental and virtual waves (A and C) share similar features, namely, the peak advances, the wave flattens, and the overall label decreases. 
All in all, the postulated stability of axonal proteins has been consistently contradicted rather than supported by the data, such that STM should either revise its tenets or collapse as a construct (Fig. 3, STM). Surprisingly, this inconsistency has not been discussed in depth, despite its important bearings on STM. Stability of proteins in axons calls for an additional ancillary assumption, namely elimination of as much protein in the terminals as the cell body pumps into the axon. This important ancillary assumption has not been studied in detail.

Scrutiny of inability of axons to synthesize proteins

The study of protein synthesis in axons began fifty years ago. However, STM did not incorporate this second source into its

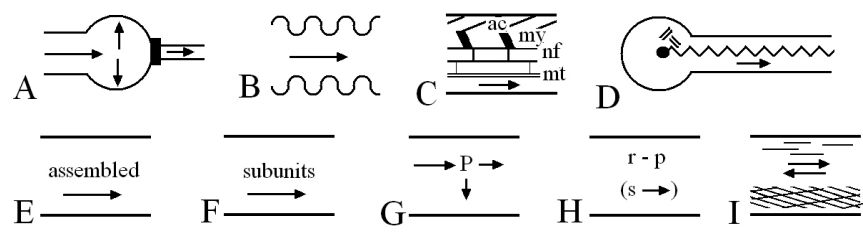

Figure 2. A selection of long distance transport mechanisms: In general, transport mechanisms have been proposed considering a restricted set of observations rather than developing a comprehensive understanding of the axon, and these mechanisms need not be mutually exclusive. A. Axoplasmic streaming $(\rightarrow)$ at $c a$ $1 \mathrm{~mm} /$ day. At the constriction (black box), the axoplasm is partially arrested $(\uparrow \downarrow)$, axons become thinner downstream and balloons are formed behind. To account for the long travel time, the model assumed that axoplasmic proteins were not degraded (Weiss and Hiscoe, 1948). If proteins are not degraded, balloons should grow ad infinitum. B. The axoplasm, considered a gel with thixotropic properties, is propelled $(\rightarrow)$ by peristaltic waves. These occur at about $30 \mathrm{~min}$ intervals, regardless of whether the continuity of the axon is preserved or disrupted by degenerative fragmentation (Weiss, 1972). C. Neurofilaments (nf) are cross-linked between them and with microtubules (mt). Myosin (my) bridges $\mathrm{nf}$ to actin filaments (ac) that are attached to the axolemma; myosin develops the force that moves the cytomatrix away from the cell body $(\rightarrow)$. No experimental support is given (Hoffman and Lasek, 1981). D. The cytoskeleton is likened to a continuous rope (wavy line) attached to its site of assembly in the cell body (black sphere), and slow transport proceeds $(\rightarrow$ ) only if newly synthesized elements (short lines) are inserted in the cell body. However, the velocity of transport is regulated by some mechanism in the axon or its terminals. Supporting evidence: systemic inhibition of protein synthesis arrests the slow wave but nerve section does not (Grafstein and Alpert, 1982). E. Polymers move down the axon while monomers do not (Baas and Brown, 1997). F. Sububunits move down the axon while polymers do not (Hirokawa et al., 1997). G. A column P leaves the perikaryon; then as proteins are degraded $(\downarrow)$ the moving column $P$ (long horizontal arrow) shortens (short horizontal arrow) to maintain the packing of moving proteins. The axon is uniform and its length is determined by the size of the bolus that the cell body pumps into the axon in a unit time (Miller and Samuels, 1997). The postulated shortening of the moving column is not in accordance with the lengthening of the putative boluses, which are the observed waves (Fig. 1, A). $\mathrm{H}$, rapid movements $(\mathrm{r})$ of cytoskeletal polymers assisted by fast motors, followed by prolonged pauses ( $p$ ) results in the apparent slow transport $(\mathrm{s} \rightarrow$ ); no permanent stationary matrix (Brown, 2000). I, in sufficiently matures axons, ca $90 \%$ of the cytoskeleton is stationary while $10 \%$ presents rapid movements in either direction followed by prolonged pauses (Yuan et al., 2009). basic notions since the idea that axons are unable to synthesize proteins was, and still is, deeply rooted. The study of these two putative sources of axoplasmic protein - transport from the cell body and local synthesis - have followed separate tracks to date. Pioneering studies by Edström, Giuditta and Koenig showed that amino acids are incorporated into the axoplasm by a mechanism sensitive to protein synthesis inhibitors, and newly synthesized proteins are typical of the axoplasm (Edström, 1966; 1967; Koenig, 1967; Giuditta et al., 1968; Edström and Sjöstrand, 1969); for early reviews, see Koenig (1970; 1984) and Giuditta (1980).

Within STM, the axoplasm has occasionally been acknowledged to synthesize proteins, but the rate has been deemed as negligible to account for the ongoing replacement as compared to role of transported proteins (Droz and Koenig, 1970). However, the volume of the axoplasm was not considered and it may balance its low rate of synthesis. The relative contribution of the cell body and axoplasm to the protein balance of the neuron was addressed in the Mauther neuron of goldfish in vivo (Alvarez and Benech, 1981). Amino acid incorporation into axoplasmic proteins was $1.7-4.2 \%$ per unit of volume compared to that of the cell body. Owing to the enormous volume of the axon, total incorporation into it was 20 to 50fold that of its cell body. More recently, in sympathetic neurons in culture, axons were reported to incorporate $10 \%$ that of an equal volume of cell bodies (Lee and Hollenbeck, 2003). These results support the view that the synthetic capacity of axons is substantial, all the more that the axoplasmic volume, albeit variable, may reach over a thousand-fold that of its cell body.

Components of the machinery for protein synthesis were also found in axons. Axoplasmic RNAs were collected and

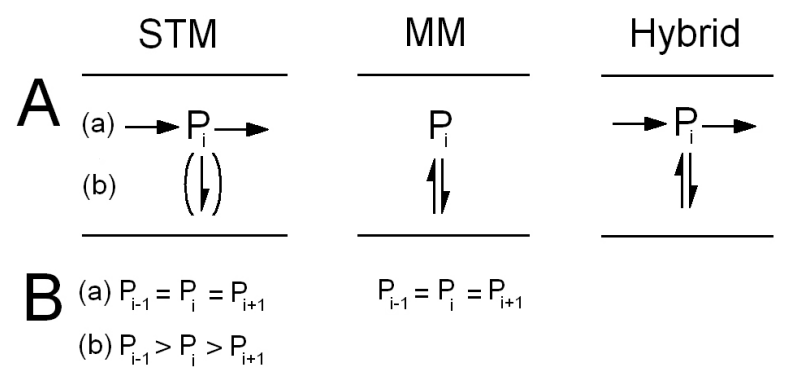

Figure 3. Maintenance of the axoplasm: kinetics of STM (slow transport model), MM (metabolic model) and Hybrid. Upper panels, theoretical models. $\mathrm{Pi}$, protein in a unit segment of axon; $\rightarrow$, vectorial transport; $\uparrow$, synthesis and $\downarrow$, degradation of Pi. Lower panels, compartment analysis. STM (a): the cell body pumps an amount $P$ into the first axonal segment in a unit of time; simultaneously, every segment transfers $P$ to the following segment, and the terminals eliminate the same amount. $\left(a^{\prime}\right)$; the axon is uniform and in a steady state. (b): degradation of protein ( $\downarrow$ ) albeit negated by STM was supported by data at the time of STM inception. (b'), by introducing $(\downarrow)$ in the unit segment, $P$ decreases continuously with distance, yielding non-uniform axons. MM, upper panel, synthesis and degradation of $\mathrm{Pi}$ occurs in place, processes regulated on a local basis; segments are alike and in a steady state. Note that long distance transport of $P$ does not appear in MM. Lower panel, $\mathrm{P}$ is similar in all segments by definition. Hybrid, long distance transport co-exists with local synthesis and degradation of proteins, hence Pi has two sources. The conditions under which this hybrid model yields uniform axons have to be established. 
identified as ribosomal, messenger and transfer (Edström et al., 1962; 1969; Black and Lasek, 1977; Koenig, 1979; Ingoglia et al., 1983; Jirikowski et al., 1990; Mohr and Richter, 1992; Wensley et al., 1995). Notwithstanding, the role of axoplasmic RNAs has been controversial as it was deemed unrelated to local protein synthesis (Black and Lasek, 1977; Ingoglia et al., 1983; Jirikowski et al., 1990; Mohr and Richter, 1992; Wensley et al., 1995) since the notion that axons do not synthesize proteins prevailed. If we track this deeply rooted notion back to its roots, we find that electron microscopists did not include ribosomes in the inventory of the axoplasm, and that cell biologists considered axons to be ribosome-free, based on this one and only datum. Is electron microscopy reliable enough to assert that axons do not contain ribosomes? Does this single negative finding outweigh the positive evidence for protein synthesis in axons? Since STM was conceived to explain the supply of proteins to ribosome-free axons, this notion is uncompromising, and if ribosomes do occur in axons, STM should be revised or rejected. A published electron micrograph shows polyribosomes in the axoplasm but they were not reported (Peters et al., 1991) (Fig. 4, A), which emphasizes the limits of electron microscopy to reveal small, sporadic, and inconspicuous structures. More recently, axonal ribosomes have been searched for and revealed with riboprobe, immunocytochemistry, electron spectroscopic imaging, and both standard and immuno electron microscopy (Fig. 4, B, C) (Giuditta et al, 1991; Koenig et al., 2000; Sotelo-Silveira, 2004; Kun et al., 2007; Court et al., 2008). Interestingly, in peripheral nerves in vivo, Schwann cells have been shown to supply ribosomes to axons (Court et al., 2008; 2011), which adds an unsuspected dimension to the supply of protein to axons, as

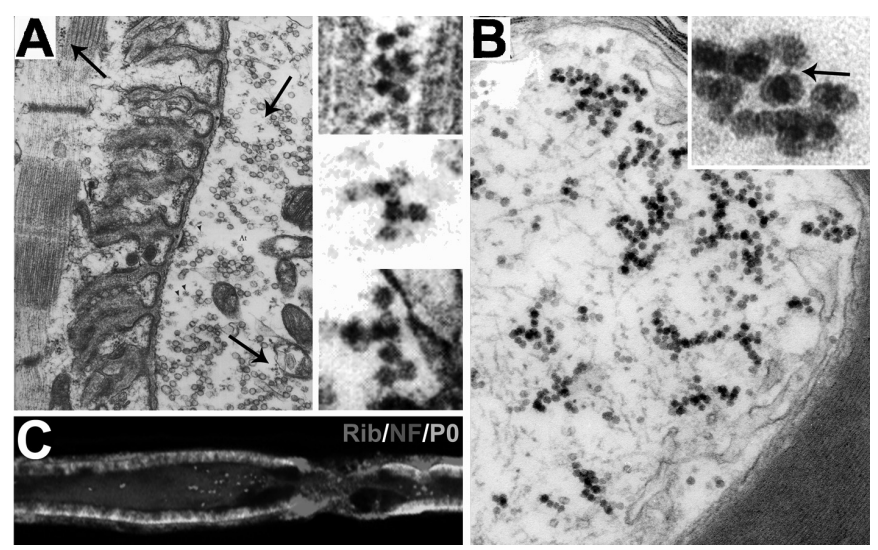

Figure 4. Ribosomes in axoplasm. A, electron micrograph of a motor end plate (from Fig. 5-2, in Peters et al., 1991; by permission of Oxford University Press). Arrows point to polyribosomes, which are shown enlarged in the same sequence in the right panels. Top panel: polyribosome in the muscle cell, for comparison. Center and bottom panels: polyribosomes in the axoplasm of the terminal. They were not mentioned in either the legend or the text. B and C, sciatic nerve fibers of Wld $\mathbf{d}^{\mathrm{s}}$ mouse severed for over a week. B, electron micrograph; fiber exhibits a field of ribosomes in the axoplasm. Inset: a polyribosome, where a strand connects two adjacent ribosomes (arrow). C, immunostaining of a teased fiber including a node of Ranvier. Color codes are indicated: Rib, ribosome; NF, neurofilament; PO, myelin protein zero. Ribosomes (red puncta) are immersed in the neurofilament space. well as to the biology of the axon-glia unit (cf Giuditta et al., 2008).

In recent years, studies relating to proteins synthesis in axons have been explosive. The repertoire of proteins locally synthesized in axons is extensive in terms of type and functions, e.g., cytoskeletal proteins, chaperones, resident endoplasmic reticulum proteins, anti-oxidant and metabolic proteins, membrane receptor proteins and many more. In addition, protein synthesis in axons has been described in different sub-compartments and as being responsible for diverse local functions, including translation at synapses or sensory receptors, synthesis in elongating and regenerating axons and growth cones, protein synthesized at the site of injury to be transported to the perikaryon as signals (Crispino et al., 1997; Gaete et al., 1998; Martin et al., 1998; Sotelo et al., 2000; 2008; Brittis et al., 2002; Calliari et al., 2002; Zhang et al., 2002; Hanz et al., 2003; Piper et al., 2005; Verma et al., 2005; Willis et al., 2005; Wu et al., 2005; van Kesteren et al., 2006; Jiménez-Díaz et al., 2008; Dubacq et al., 2009; Hengst et al., 2009; Toth et al., 2009); for reviews, see (Álvarez et al., 2000; Campenot and Eng, 2000; Martin, 2004; Lin and Holt, 2008; Giuditta et al., 2008).

The study of the machinery for protein synthesis in axons is also thriving, e.g., differential localization of periaxoplasmic ribosomal plaques along axons and their molecular organization, identification mRNAs, profile and translation of axonal mRNAs, regulation of RNAs during synaptogenesis, trafficking of RNA, learning as a modulator of synaptic mRNAs, changes of the RNA repertoire during development and injury, even mRNAs coding for myosin Va heavy chain, and cytochrome c oxidase, a mitochondrial protein coded in the nucleus, have been identified in the axoplasm. Regulation of protein synthesis at the mRNA level is also operational in axons, including RNA interference (Wensley et al., 1995; Olink-Coux and Hollenbeck, 1996; Calliari et al., 2002; Lee and Hollenbeck, 2003; Sotelo-Silveira et al., 2004; 2008; Willis et al., 2005; Lyles et al., 2006; Kun et al., 2007; Murashov et al., 2007; Willis et al., 2007; Aschrafi et al., 2008; Brisbal et al., 2009; Ferrara et al., 2009; Taylor et al., 2009; Vogelaar et al., 2009; Gunny et al., 2010; Zivraj et el., 2010); for recent reviews, see Sotelo-Silveira et al. (2006), Koenig (2009), Vuppalanchi et al. (2009), Yoon et al. (2009) and Yoo et al. (2010).

Summing up, in the early days of electron microscopy, ribosomes were not reported in axons. This datum, produced with a method that was not sufficiently sensitive (vide supra), was taken to signify 'axons do not synthezise proteins'. In this scenario, STM was developed to understand how cell bodies supply requisite proteins to ribosome-free axons whereby its rationale hangs from the truth of this notion. Since its inception, STM has not revised or updated the postulated inability of axons to synthesize proteins. Another avenue of research established that axons contain ribosomes, synthesize a large amount and an extensive repertoire of proteins. Therefore, 'axons do not synthesize proteins' is an untrue notion that arose from overrating a single negative and unreliable datum. The occurrence of protein synthesis in axons removes the very purpose of STM, and makes untrue its ancillary assumption, namely, that cell bodies supply the bulk of axoplasmic proteins. Surprisingly, this riddle has not been brought to the fore despite that it calls for a thorough revision of the tenets of STM, given that its validity is seriously questioned (Fig. 3, Hybrid). 


\section{Scrutiny of the slow waves}

The slow radioactive waves that invade axons were considered compelling evidence for transport, and rightly so, on condition that axons do not synthesize proteins. Since axons do not meet the condition, the highly compelling status of the radioactive waves is downgraded to that of modestly supporting evidence for transport, making the waves open to alternative interpretations. Below we will show that the dynamics of synthesis and degradation of protein in axons generates radioactive waves progressing through stationary axoplasmic proteins.

Intraaxonal injection of tracers at a distance from the cell body was revealing. The newly synthesized proteins in the axoplasm presented a bell-shaped profile that spread over 10 millimeters from the site of injection within $90 \mathrm{~min}$ (Fig. 1, B) (Álvarez and Chen, 1972), i.e., substantial diffusion of the tracer and its local incorporation into proteins occur concurrently. This finding has important bearings on the interpretation of reported data. For example, Lasek et al. (1993) injected the eye with tracers and the labeled neurofilament waveform front was distinguished in the optic nerve behind the eye. Measurements interpreted under STM yielded transport rates ranging between 72 and $144 \mathrm{~mm} /$ day, two orders of magnitude greater than the usual estimates. We propose an alternative explanation: precursors diffuse from cell bodies into optic nerve axons and newly synthesized proteins are labeled in the process. Thus the recovery of labeled proteins becomes a readout of amino acid diffusion. In this interpretation, the underlying mechanism is well supported by evidence and does not require translocation of protein, hence the putative transport mechanism becomes an unnecessary explanatory construct, at variance with the authors' view.

Can diffusion of tracers and local incorporation alone generate radioactive waves progressing through stationary axoplasmic proteins? The answer is yes. The metabolic model $(\mathrm{MM})$ for a unit segment is shown in Figure 1B' (cf Table 1) and includes: (i) local synthesis and degradation of proteins; (ii) axial diffusion of amino acids in the axoplasm, and (iii) their uptake from, and leakage to, the extracellular space. Axoplasmic proteins are stationary but local displacements from the site of synthesis to destination are expected. When tracers are administered to cell bodies, (i) they are taken up efficiently, (ii) diffuse freely into the axon, and (iii) are incorporated into axonal proteins reflecting the specific activity of the local pool (Fig. 1, C'). Newly synthesized proteins in the axon reflect the decreasing specific activity with distance and a wave front of labeled proteins arises (cf Fig. 1, B). Diffusing tracers keep recruiting axonal segments and by labeling newly synthesized proteins, the front progresses continuously. Protein degradation re-supplies the soluble pool with tracers. In the proximal segments, retro-diffusion to the cell body reduces the specific activity of tracers, and eventually a peak comes into being in the axonal proteins. Partial re-cycling of tracers decreases the overall label of proteins. Nixon (1980) showed that the release of labeled amino acids from nerves was enhanced by cycloheximide, an inhibitor of protein synthesis, and concluded that amino acids were re-cycled in the nerve. This observation lends experimental support to this tenet of MM.

To assess the predictive power of MM, the kinetics of protein synthesis and diffusion of tracers were expressed as a set of differential equations for a unit segment (Fig. 1, B').
Constants for synthesis and degradation of proteins, and for diffusion, uptake and leakage of amino acids were taken or derived from published values, and the equations solved by iteration (Álvarez and Torres, 1985). Virtual waves are similar to observed waves in several respects: (i) with time, the peak moves away, albeit its velocity is in the lower range of reported values, (ii) the leading slope becomes less steep, and (iii) the overall label decreases (Fig. 1, C). This simulation is elementary, as protein metabolism includes more variables than MM does, and the data from which constants were derived may be inaccurate and the errors could be amplified by iteration. Despite these shortcomings, the simulation showed that local synthesis generates waves of label, whereby observed waves are no longer compelling for protein transport, as is currently accepted.

The simulation, with plausible modifications, mimics other observed facts. For example, two co-existing proteins with different half-lives present peaks that progressively separate in space, the shorter the half-life, the faster the associated wave (see Fig. 9, in Alvarez and Torres, 1985), which reminds components $\mathrm{a}$ and $\mathrm{b}$ of the slow wave (Black and Lasek, 1980). In the simulation, when the cell body is made to re-supply the axon with precursors, the virtual maximum stays in the first segment throughout the post-pulse period, (see Fig. 10, in Álvarez and Torres, 1985). In goldfish, following a pulse of tracers to the eye, the radioactive maximum remains in the first segment of the optic nerve throughout the survival time (Grafstein and Murray, 1969). To close this section, we will examine the protein content along the axon. In whatever model, the content of a given axonal segment is the sum of proteins of all ages. According to STM, each time curve of Figure $1 \mathrm{~A}$ is the distribution in space of proteins of the same age. For that reason, the sum of curves for all ages yields the protein profile along the axon. From experimental data and its tenets, STM predicts that the protein content of axons should be enormous close to the cell body and vanishingly small towards the distal regions, in sharp contradiction to real axons. To our knowledge, this overt inconsistency has not been discussed by defenders of STM. For MM, all segments are similar and in a steady state, hence axons are uniform.

We showed above how waves of radioactivity can progress through stationary proteins, similar to sound waves that propagate through molecules that are not transported. This alternative interpretation of waves has many implications. As examples: (i) the standard practice to take a slow radioactive wave for moving proteins is unwarranted, (ii) the cell body origin of an axoplasmic protein is not warranted by its labeling, and (iii) when radioactive tracers are used, estimates of axoplasmic protein survival are overestimated as re-cycling of amino acids is ignored. For additional inconsistencies of STM, see Álvarez (1992) and Álvarez et al. (2000).

Slow transport has been largely characterized with metabolic labeling of proteins. As with protein degradation, genetic engineering also permits an alternative method to test waves of moving proteins in vivo by assessing the amount of a specific protein in the axon instead of the amount of label. When the transgene is turned off, STM predicts a proximodistal depletion of the foreign protein in the axon, and when it is turned on, a proximo-distal reappearance (Fig. 5, STM). The mouse that expresses only hNFL (vide supra) was used to this end. Experimentally, when the transgene was switched off with doxycycline, hNFL disappeared synchronously along 
the entire sciatic nerve, and when the gene was turned on, hNFL reappeared and accumulated within one week with no wavefront (Millecamps et al., 2007). Since predicted waves of proteins were not observed, STM does not pass the test and supplementary assumptions are necessary to rescue the model; alternatively, STM may choose to revise its tenets. In contrast, $\mathrm{MM}$ asserts that proteins are synthesized in place, stay in place, and are degraded in place hence when the gene is switched off, MM predicts a depletion of the protein along the entire axon, and the converse when it is switched on (Fig. 5, MM). That is, MM passes the test.

In brief, STM considers radioactive waves as the long distance transport of axonal proteins and must postulate a transport mechanism at the molecular level. However, when a wave of a defined protein is being sought instead of a wave of label, the former does not show up, i.e., the tenets of STM are insufficient to explain the phenomenon. In contrast, in $\mathrm{MM}$, waves of radioactivity arise as an inconsequential epiphenomenon of diffusion of precursors and their local incorporation while proteins are stationary. Moreover, MM also accounts for the various rates or shapes of the experimental waves based on well-known processes, such as the turnover rate of proteins or the dynamics of the amino acid pool.
STM

\begin{tabular}{|c|c|c|c|c|c|c|c|c|}
\hline $\operatorname{Tg} \mathrm{T}$ & CB & A 1 & A 2 & A 3 & CB & A 1 & A 2 & A 3 \\
\hline $\begin{array}{l}O \\
f\end{array}$ & $\begin{array}{l}\mathrm{P}_{1} \rightarrow \\
\text {. }\end{array}$ & $\rightarrow \mathrm{P} \rightarrow$ & $\rightarrow \mathrm{P} \rightarrow$ & $\rightarrow \mathrm{P} \rightarrow$ & $\begin{array}{c}P \\
11\end{array}$ & P & $\begin{array}{l}P \\
11\end{array}$ & $\begin{array}{l}P \\
11\end{array}$ \\
\hline f & 1 & & $\rightarrow \mathrm{P} \rightarrow$ & $\rightarrow \mathrm{P} \rightarrow$ & $\begin{array}{l}\mathrm{P} \\
\mathrm{b}\end{array}$ & $\begin{array}{l}\mathrm{P} \\
\mathrm{f}\end{array}$ & $\begin{array}{l}P \\
b\end{array}$ & $\begin{array}{l}P \\
P\end{array}$ \\
\hline 2 & 1 & & & $\rightarrow \mathrm{P} \rightarrow$ & $\begin{array}{l}\mathrm{P} \\
\mathrm{i}\end{array}$ & $\stackrel{p}{p}$ & $\begin{array}{l}P \\
b\end{array}$ & $\begin{array}{l}P \\
P \\
\end{array}$ \\
\hline 3 & 1 & & & & 1 & 1 & $b$ & 1 \\
\hline
\end{tabular}

Figure 5. Predictions of STM, slow transport model and MM metabolic model upon turning a transgene off or on. In a transgenic mouse, $\mathrm{Tg}$ codes for an axoplasmic protein $\mathrm{P}$ under negative control. $T$, time sequence $0-3 ; C B$, cell body; $A 1-A 3$, sequence of axonal segments; size of $P$ stands for amount; $\rightarrow$, vectorial transport of $\mathrm{P}$. Half arrow pointing up, synthesis, and half arrow pointing down, degradation of proteins. At time 0 , the system is in a steady state. Box off. At time $0, \mathrm{Tg}$ is turned off. STM: in the cell body, synthesis of $P$ is halted while existing $P$ in the axon keeps moving toward the terminals ensuing a proximodistal clearing of P. MM: in the axoplasm, synthesis of $\mathrm{P}$ is halted and degradation of $P$ becomes unbalanced (half arrow pointing down) leading to a decrease of $P$ along the entire axon. Box on. At time $0, \mathrm{Tg}$ is turned on. STM: in the cell body, synthesis of $P$ restarts and the depleted axon is re-supplied with $\mathrm{P}$ resulting in a proximo-distal reappearance of P. MM: in the axon, synthesis of $P$ restarts everywhere (half arrow pointing up), resulting in an accumulation of $\mathbf{P}$ along its entire length. Predictions of $\mathbf{M M}$ are in agreement with the results (see text).
On the other hand, as MM excludes long distance transport of proteins, waves of proteins should not occur, i.e., MM accounts for a broader scope of phenomena without additional assumptions, and not even a transport mechanism is necessary.

Our cursory scrutiny of STM indicates that both old and recent experimental evidence challenges STM on all sides. Two pillars - the inability of axons to synthesize proteins, and the stability of proteins - have been disproven, which by implication disproves the ancillary notions that axonal proteins originate in the cell body and that they are eliminated at the terminals. Finally, the last pillar - the waves of label once compelling evidence for transport, can be explained by protein synthesis in the axoplasm. As the supporting evidence for STM is far from satisfactory, STM can no longer be taken for granted. As an example, let us consider the cytoskeletal assemblies that move in the axoplasm (vide supra), which are considered to originate in the cell body. This assumption is now clearly invalid whereby the site of synthesis of their components, cell body or axoplasm, has to be established by experiment in order to assign these moving assemblies their proper role. Taking all our scrutiny together, we think that STM must be revised in the light of present day information even if no alternative model were at hand. Our goal is to have a coherent and well-supported understanding of axons. Thus it seems reasonable to develop an updated model with the whole body of knowledge dealing with the supply of proteins to axons rather than fostering a particular model with selected data.

\section{Experimental discrimination between STM and MM}

To discriminate between alternative explanations for a set of observations, it is customary that the challenger has to propose a protocol in which the contending models lead to radically different predictions. In the transgenic mouse commented above, besides the test for waves that MM passed, other tests can be visualized. For example, in the mouse that expresses hNFL, the messenger for this foreign subunit has not been assessed so far in the sciatic nerve. MM predicts its occurrence in the nerve, particularly when the transgene is turned on (Fig. 5 , on, MM). This strong prediction of MM, which requires a highly sensitive method, is not a crucial test, sensu stricto, as STM may claim that messengers are not translated in the axoplasm (cf. Jirikowski et al., 1990; Mohr and Richter, 1992). Below we propose a classical metabolic protocol, unpublished to our knowledge, that leads to irreconcilable predictions (Fig. 6). A pulse of $\mathrm{S}^{35}$-methionine and $\mathrm{H}^{3}$-glycine is administered to cell bodies. STM predicts that a defined protein, e.g., neurofilament light subunit, is imprinted in the cell body with a certain ratio between labels $\left(\mathrm{S}^{35} / \mathrm{H}^{3}\right)$, sort of hallmark of birth. Thereafter the protein must exhibit this hallmark when it is recovered from the axon at whatever place or whatever time (Fig. 6, STM). In contrast, MM holds that proteins reflect the specific activity of the local pool. As tracers diffuse from cell body along the axon, $\mathrm{H}^{3}$-glycine, owing to its many alternative pathways, is removed more efficiently than $\mathrm{S}^{35}$-methionine. As a consequence, the specific activity of $\mathrm{H}^{3}$-glycine falls with distance faster than that of $\mathrm{S}^{35}$-methionine (Fig. 6, MM). Therefore, $\mathrm{MM}$ predicts that $\mathrm{S}^{35} / \mathrm{H}^{3}$ in the defined protein increases with distance from the cell body. Upon proteolysis, released $\mathrm{H}^{3}$-glycine further falls relative to $\mathrm{S}^{35}$-methionine, whereby re-cycling further increases $\mathrm{S}^{35} / \mathrm{H}^{3}$ over time in the 
protein of interest. We invite an unbiased third party to carry out this experiment, or any other protocol that discriminate between models, to shed light on the understanding of the origin of axonal proteins.

\section{Looking forward}

A model for the supply of proteins to axons must comply simultaneously with several constraints. In particular, the model should give rise without strains to axons (i) of any length (ii) rather uniform along their trajectory, but allow for regional variation, e.g., changes of caliber, branching; and (iii) in a steady state, but allow for transient or permanent local responses, e.g., sprouting, pruning, growth, steering; (iv) the phenomenology pertaining to the field should spring directly from the dynamics of the model, (v) the model has to assign a role to synthesis and degradation of protein in axons; finally (vi) the model should not include unrealistic assumptions. To be acceptable, a model for the supply of axoplasmic proteins has to be gauged by these restrictions.

It is clear now that axons synthesize and degrade proteins, and that cell bodies are not the main supplier of axonal proteins, thus contradicting the tenets of STM. As a theory, STM is now bound to include these notions under penalty of being overtly incomplete, i.e., STM will become a hybrid (Fig. 3, Hybrid). More importantly, all conclusions derived from the
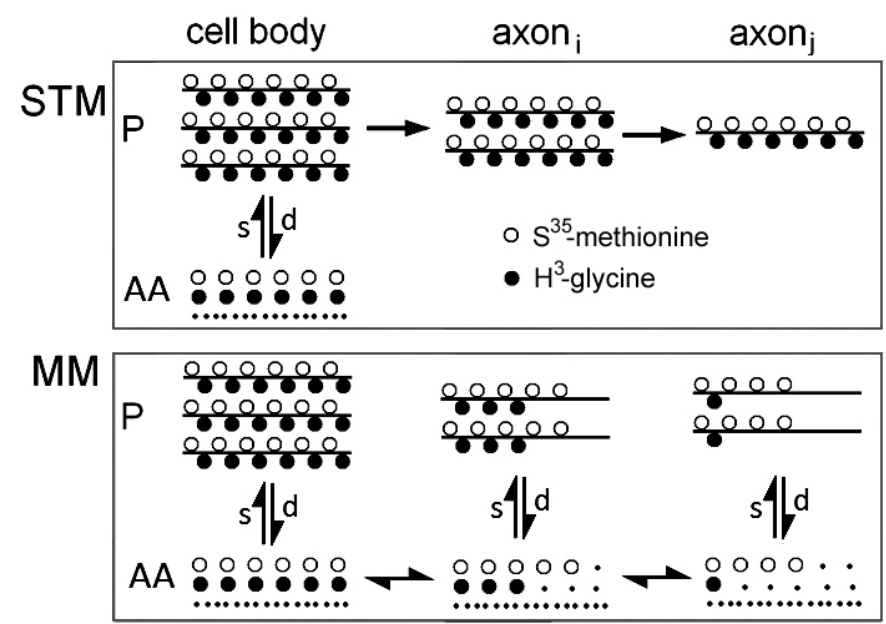

Figure 6. Protocol to discriminate between STM and MM. Metabolic labeling of axoplasmic proteins after a pulse of $\mathrm{S}^{35}$ methionine and $\mathrm{H}^{3}$-glycine administered to the cell body. Axon and axon $_{j}$ are successive, but not adjacent segments. $P$ is a defined protein and AA is a pool of amino acids, where dots represent unlabeled amino acids. Half arrows indicate synthesis (s) and degradation (d) of proteins. Box STM, in the cell body, $P$ is imprinted with a hallmark $\left(\mathrm{S}^{35} / \mathrm{H}^{3}\right)$, and transported $(\rightarrow)$ to the axoplasm; thereafter, $\mathrm{S}^{35} / \mathrm{H}^{3}$ cannot change, irrespective of space or time. If degraded, surviving $P$ still exhibits the same $S^{35} /$ $\mathrm{H}^{3}$ (axon $_{\mathrm{i}}$ and axon $_{\mathrm{j}}$ ). In the axoplasm, AA (not shown) has no role. Box MM, axoplasmic proteins are synthesized locally. As tracers diffuse down the axon (horizontal double half arrow) the specific activities in AA decline with distance but more so that of $\mathrm{H}^{3}$ - glycine, which is removed by its many metabolic pathways. In axon $_{i}$ and axon $_{\mathrm{j}}$, corresponding $\mathrm{P}$ reflects the local specific activity hence in $\mathrm{P}, \mathrm{S}^{35} / \mathrm{H}^{3}$ increases with distance and also with time, as $\mathrm{H}^{3}$-glycine is further removed during re-cycling. tenets of STM to the present time are provisionally flawed. In fact, the body of data was produced by real axons that used cellular mechanisms that STM ignored. Therefore, to draw valid conclusions, this body of evidence must be re-interpreted using the tenets of STM, plus local synthesis, degradation of axoplasmic proteins, and the diffusion and re-cycling of amino acids.

We want to highlight two salient facts for their important implications. The first is the intermittent and bidirectional displacement of cytoskeletal assemblies in axons (Brown, 2000; Roy et al., 2000; Wang et al., 2000; Yuan et al., 2009). The clarification of the origin, destination and motors, composition, turn over and regulation of these assemblies, among other issues, will greatly improve our understanding of axons. The second fact is that axonal ribosomes originate in the Schwann cell (Court et al., 2008; 2011; cf Li et al., 2005a) as also RNAs (Sotelo-Silveira et al., 2000; Eyman et al., 2007). This unprecedented mechanism opens a broad avenue of inquiry relating to protein synthesis in axons, to the biology of the axon-glia unit, and probably extensively to interactions between other cellular associations.

\section{Concluding remarks}

The extreme geometry of axons has posed a double challenge, namely, for axons to get their proteins and for scientists to disclose the underlying mechanism. It is our view that the perikaryonal origin of axoplasmic proteins and their subsequent transport were sound notions posited in their time to account for axons that were believed to be unable to synthesize proteins. These notions, complemented with appropriate assumptions to fill gaps, were accepted by the scientific community, and are still standard textbook notions. Regrettably, when inconsistencies arose, some were addressed with unsupported assumptions, and others went unnoticed or ignored (cf Álvarez and Torres, 1985; Álvarez, 1992; Álvarez et al., 2000), and were never discussed at large.,

We have scrutinized STM and if we have cast doubts on its validity, our effort has been successful. We have purposely highlighted old data to show that their implications could have prompted the advocates of STM to revise the tenets of the model and to address some important issues. On the other hand, axons have been shown to synthesize a large amount, and a wide variety, of proteins, and account for the phenomenology without strain pertaining. Consequently, it is also our view that at present there is no compelling evidence to claim that the cell body supplies the bulk of axoplasmic proteins to the terminals. However, if both cell body and axoplasm supply axonal proteins, the cell body is no longer the default source, as currently accepted, and the contribution of each source for every axonal protein must be established by experiment.

The study of local synthesis began a few years after that of axoplasmic transport. Although both addressed the supply of protein to axons, they followed separate tracks with no crosstalk, probably because the question of local synthesis had a low profile for years. We have shown that the origin of axoplasmic proteins is an open question and we think that the study of protein supply to axons has reached a turning point that offers a broader horizon to be explored. Crosstalk between advocates of transport and of local synthesis will improve our understanding of axons and provide a fresh conceptual 
framework whereby the maintenance and development of axons, nerve repair, axonopathies and neurological disorders, among other fields, will be considered in a new light. We hope that these dissenting views will stimulate debate for the benefit of our understanding of the neuron, and it is likely that an enriched picture will emerge to enlighten future research.

\section{ACKNOWLEDGEMENTS}

This work was supported by grants from the government of Chile: FONDECYT no. 1110987, and Millennium Nucleus no. P07-011-F.

\section{REFERENCES}

ÁLVAREZ J (1992) Maintenance of the axoplasm: can neurons accord with the accepted notions? Neurosci Lett 144: 1-3.

ÁLVAREZ J, BENECH CR (1983) Axoplasmic incorporation of amino acids in a myelinated fiber exceeds that of its soma: a radioautographic study. Exp Neurol 82: 25-42.

ÁLVAREZ J, CHEN WY (1972) Injection of leucine into a myelinic axon: incorporation in the axoplasm and transfer to associated cells. Acta Physiol Lat Am 22: 266-269.

ÁlVAREZ J, GIUDITTA A, KOENIG E (2000) Protein synthesis in axons and terminals: significance for maintenance, plasticity and regulation of phenotype. With a critique of slow transport theory. Prog Neurobiol 62: $1-62$.

ÁLVAREZ J, TORRES JC (1985) Slow axoplasmic transport: a fiction? J Theor Biol 112: 627-651.

ASCHRAFI A, SCHWECHTER AD, MAMEZA MG, NATERA-NARANJO O, GIOIO AE, KAPLAN BB (2008) MicroRNA-338 regulates local cytochrome c oxidase IV mRNA levels and oxidative phosphorylation in the axons of sympathetic neurons. J Neurosci 28: 12581-12590.

BAAS PW, BROWN A (1997) Slow axonal transport: the polymer transport model. Trends Cell Biol 7: 380-384

BISBAL M, WOJNACKI J, PERETTI D, ROPOLO A, SESMA J, JAUSORO I, CÁCERES A (2009) KIF4 mediates anterograde translocation and positioning of ribosomal constituents to axons. J Biol Chem 284: 9489-9497.

BLACK MM, LASEK RJ (1977) The presence of transfer RNA in the axoplasm of the squid giant axon. J Neurobiol 8: 229-237.

BLACK MM, LASEK RJ (1980) Slow components of axonal transport: two cytoskeletal networks. J Cell Biol 86: 616-623.

BRADY ST, COLMAN DR, BROPHY PJ (2008) Subcellular organization of the nervous system: organelles and their functions. In: SQUIRE L, BERG D, BLOOM F, DU LAC S, GOSH A, SPITZER N (eds) Fundamental Neuroscience 3rd ed. Amsterdam: Elsevier (Academic Press). pp: 59-86

BRIDGMAN PC (2004) Myosin-dependent transport in neurons. J Neurobiol 58: $164-174$.

BRITTIS PA, LU Q, FLANAGAN JG (2002) Axonal protein synthesis provides a mechanism for localized regulation at an intermediate target. Cell 110: 223-235.

BROWN A (2000) Slow axonal transport: stop and go traffic in the axon. Nat Rev Mol Cell Biol 1: 153-156.

CALLIARI A, SOTELO-SILVEIRA J, COSTA MC, NOGUEIRA J, CAMERON LC, KUN A, BENECH J, SOTELO JR (2002) Myosin Va is locally synthesized following nerve injury. Cell Motil Cytoskeleton. 51: 169-176.

CAMPENOT RB, ENG H (2000) Protein synthesis in axons and its possible functions. J Neurocytol 29: 793-798.

CANCALON P (1979) Infuence of temperature on the velocity and on the isotope profile of slowly transported labeled proteins. J. Neurochem 32: 997-1007

COURT FA, HENDRIKS WTJ, MACGILLAVRY HD, ÁLVAREZ J, VAN MINNEN J (2008) Schwann cell to axon transfer of ribosomes: toward a novel understanding of the role of glia in the nervous system. J Neurosci 28: 11024-11029.

COURT FA, MIDHA R, CISTERNA BA, GROCHMAL J, SHAKHBAZAU A, HENDRIKS WT, VAN MINNEN J (2011) Morphological evidence for a transport of ribosomes from Schwann cells to regenerating axons. Glia 59: 1529-1539.

CRISPINO M, KAPLAN BB, MARTIN R, ÁLVAREZ J, CHUN JT, BENECH JC, GIUDITTA A (1997) Active polysomes are present in the large presynaptic endings of the synaptosomal fraction from squid brain. J Neurosci 17: 7694-7702.
DAHLSTROM AB, CZERNIK AJ, LI JY (1992) Organelles in fast axonal transport. What molecules do they carry in anterograde vs retrograde directions, as observed in mammalian systems? Mol Neurobiol 6: $157-177$.

DROZ B, KOENIG HL (1970) Localization of protein metabolism in neurons. In: LAJTHA A (ed) Protein metabolism in the nervous system Plenum Press, New York pp: 93-108

DROZ B, KOENIG HL, DI GIAMBERARDINO L (1973) Axonal migration of protein and glycoprotein to nerve endings. I. Radioautographic analysis of the renewal of protein in nerve endings of chicken ciliary ganglion after intracerebral injection of (3H)lysine. Brain Res 60: 93-127.

DROZ B, LEBLOND CP (1963) Axonal migration of proteins in the central nervous system and peripheral nerves as shown by radioautography. J Comp Neurol 121: 325-346.

DUBACQ C, JAMET S, TREMBLEAU A (2009) Evidence for developmentally regulated local translation of odorant receptor mRNAs in the axons of olfactory sensory neurons. J Neurosci 29: 10184-10190."

EDSTRÖM A (1966) Amino acid incorporation in isolated Mauthner nerve fibre of goldfish. J Neurochem 13: 315-321.

EDSTROM A, SJOSTRAND J (1969) Protein synthesis in the isolated Mauthner nerve fibre of goldfish. J Neurochem 16: 67-81.

EDSTRÖM A, EDSTRÖM JE, HOÖKFELT T (1969) Sedimentation analysis of ribonucleic acid extracted from isolated Mauthner nerve fibre components. J Neurochem 16: 53-66.

EDSTROM JE, EICHNER D, EDSTROM A (1962) The ribonucleic acid of axons and myelin sheaths from Mauthner neurons. Biochim Biophys Acta 61: 178-184.

EYMAN M, CEFALIELLO C, FERRARA E, DE STEFANO R, LAVINA ZS, CRISPINO M, SQUILLACE A, VAN MINNEN J, KAPLAN BB, GIUDITTA A (2007) Local synthesis of axonal and presynaptic RNA in squid model systems. Eur J Neurosci 25: 341-350.

FERRARA E, CEFALIELLO C, EYMAN M, DE STEFANO R, GIUDITTA A, CRISPINO M (2009) Synaptic mRNAs are modulated by learning. J Neurosci Res 87: 1960-1968.

GAETE J, KAMEID G, ÁLVAREZ J (1998) Regenerating axons of the rat require a local source of proteins. Neurosci Lett 251: 197-200.

GIUDITTA A (1980) Origin of axoplasmic protein in the squid giant axon. Riv Biol 73: 35-49.

GIUDITTA A, CHUN JT, EYMAN M, CEFALIELLO C, BRUNO AP, CRISPINO M (2008) Local gene expression in axons and nerve endings: The glia-neuron unit. Physiol Rev 88: 515-555.

GIUDITTA A, DETTBARN WD, BRZIN M (1968) Protein synthesis in the isolated giant axon of the squid. Proc Natl Acad Sci U S A 59: 1284-1287.

GIUDITTA A, MENICHINI E, PERRONE CAPANO C, LANGELLA M, MARTIN R, CASTIGLI E, KAPLAN BB (1991) Active polysomes in the axoplasm of the squid giant axon. J Neurosci Res 28: 18-28.

GRAFSTEIN B, ALPERT RM (1982) Properties of slow axonal transport: studies in goldfish optic axons. In: WEISS DG (ed) Axoplasmic Transport. Berlin: Springer-Verlag. pp: 226-231.

GRAFSTEIN B, FORMAN DS (1980) Intracellular transport in neurons. Physiol Rev 60: 1167-1283.

GRAFSTEIN B, MURRAY M (1969) Transport of protein in goldfish optic nerve during regeneration. Exp Neurol 25: 494-508.

GUMY LF, TAN CL, FAWCETT JW (2010) The role of local protein synthesis and degradation in axon regeneration. Exp Neurol 223: 28-37.

HANZ S, PERLSON E, WILLIS D, ZHENG J-Q, MASSARWA RA, HUERTA JJ, KOLTZENBURG M, KOHLER M, VAN-MINNEN J, TWISS JL, FAINZILBER M (2003) Axoplasmic importins enable retrograde injury signaling in lesioned nerve. Neuron 40: 1095-1104.

HENGST U, DEGLINCERTI A, KIM H, JEON N, JAFFREY S (2009) Axonal elongation triggered by stimulus-induced local translation of a polarity complex protein. Nat Cell Biol 11: 1024-1030.

HIROKAWA N, FUNAKOSHI ST, TAKEDA S (1997) Slow axonal transport: the subunit transport model. Trends Cell Biol 7: 384-388.

HOFFMAN PN, LASEK RJ (1975) The slow component of axonal transport. Identification of major structural polypeptides of the axon and their generality among mammalian neurons. J Cell Biol 66: 351-366.

INGOGLIA NA, GIUDITTA A, ZANAKIS MF, BABIGIAN A, TASAKI I, CHAKRABORTY G, STURMAN JA (1983) Incorporation of 3H-amino acids into proteins in a partially purified fraction of axoplasm: evidence for transfer RNA-mediated, post-translational protein modification in squid giant axons. J Neurosci 3: 2463-2473.

JIMÉNEZ-DÍAZ L, GÉRANTON SM, PASSMORE GM, LEITH JL, FISHER AS, BERLIOCCHI L, SIVASUBRAMANIAM AK, SHEASBY A, LUMB BM, HUNT SP (2008) Local translation in primary afferent fibers regulates nociception. PLoS ONE 3: e1961. 
JIRIKOWSKI GF, SANNA PP, BLOOM FE (1990) mRNA coding for oxytocin is present in axons of the hypothalamo-neurohypophysial tract. Proc Natl Acad Sci U S A 87: 7400-7404.

KARLSSON JO, SJOSTRAND J (1971) Synthesis, migration and turnover of protein in retinal ganglion cells. J Neurochem 18: 749-767.

KOENIG E (1967) Synthetic mechanisms in the axon. IV. In vitro incorporation of $[3 \mathrm{H}]$ precursors into axonal protein and RNA. J Neurochem 14: 437-446.

KOENIG E (1970) Membrane protein synthesizing machinery of the axon. In: COSTA E, GIACOBINI E (eds) Biochemistry of simple neruonal models, Advances in Biochemical Psychopharmacology, vol. 2. New York: Raven. pp 305-315.

KOENIG E (1979) Ribosomal RNA in Mauthner axon: implications for a protein synthesizing machinery in the myelinated axon. Brain Res 174: 95-107.

KOENIG E (1984) Local synthesis of axonal protein. In: LAJTHA A (ed) Handbook of Neurochemistry, vol. 7. New York: Plenum. pp. 315-340

KOENIG E (2009) Organized ribosome-containing structural domains in axons. Results Probl Cell Differ 48: 173-191.

KOENIG E, MARTIN R, TITMUS M, SOTELO-SILVEIRA JR (2000) Cryptic peripheral ribosomal domains distributed intermittently along mammalian myelinated axons. J Neurosci 20: 8390-8400.

KUN A, OTERO L, SOTELO-SILVEIRA JR, SOTELO JR (2007) Ribosomal distributions in axons of mammalian myelinated fibers. J Neurosci Res 85: 2087-2098

LASEK RJ, HOFFMAN PN (1976) The neuronal cytoskeleton, axonal transport and axonal growth. Cold Spring Harbor Conf. Cell Proliferation 3: 1021-1049.

LASEK RJ, PAGGI P, KATZ MJ (1993) The maximum rate of neurofilament transport in axons: a view of molecular transport mechanisms continuously engaged. Brain Res 616: 58-64.

LEE SK, HOLLENBECK PJ (2003) Organization and translation of mRNA in sympathetic axons. J Cell Sci 116: 4467-4478.

LI YC, LI YN, CHENG CX, SAKAMOTO $\mathrm{H}$, KAWATE T, SHIMADA O, ATSUMI S (2005a) Subsurface cisterna-lined axonal invaginations and double-walled vesicles at the axonal-myelin sheath interface. Neurosci Res 53: 298-303.

LI YC, CHENG CX, LI YN, SHIMADA O, ATSUMI S (2005b) Beyond the initial axon segment of the spinal motor axon: fasciculated microtubules and polyribosomal clusters. J Anat 206: 535-542.

LIN AC, HOLT CE (2008) Function and regulation of local axonal translation. Curr Opin Neurobiol 18: 60-68.

LYLES V, ZHAO Y, MARTIN KC (2006) Synapse formation and mRNA localization in cultured Aplysia neurons. Neuron 49: 349-356.

MARTIN KC (2004) Local protein synthesis during axon guidance and synaptic plasticity. Curr Opin Neurobiol 14: 305-310.

MARTIN R, VAIDA B, BLEHER R, CRISPINO M, GIUDITTA A (1998) Protein synthesizing units in presynaptic and postsynaptic domains of squid neurons. J Cell Sci 111: 3157-3166.

MCEWEN BS, GRAFSTEIN B (1968) Fast and slow components in axonal transport of protein. J Cell Biol 38: 494-508.

MERCER JA, ALBANESI JP, BRADY ST (1994) Molecular motors and cell motility in the brain. Brain Pathol 4: 167-179.

MILLECAMPS S, GOWING G, CORTI O, MALLET J, JULIEN J-P (2007) Conditional NF-L transgene expression in mice for in vivo. Analysis of turnover and transport rate of neurofilaments. J. Neurosci. 27: 4947-4956.

MILLER KE, HEIDEMANN SR (2008) What is slow axonal transport? Exp Cell Res 314: 1981-1990.

MILLER KE, SAMUELS DC (1997) The axon as a metabolic compartment: protein degradation, transport, and maximum length of an axon. J Theor Biol 186: 373-379.

MOHR E, RICHTER D (1992) Diversity of mRNAs in the axonal compartment of peptidergic neurons in the rat. Eur J Neurosci 4: $870-876$.

MORI H, KOMIYA Y, KUROKAWA M (1979) Slowly migrating axonal polypeptides. Inequalities in their rate and amount of transport between two branches of bifurcating axons. J Cell Biol 82: 174-184.

MURASHOV AK, CHINTALGATTU V, ISLAMOV RR, LEVER TE, PAK ES, SIERPINSKI PL, KATWA LC, VAN SCOTT MR (2007) RNAi pathway is functional in peripheral nerve axons. FASEB J 21: 656-670.

NIXON RA (1980) Protein degradation in the mouse visual system. I. Degradation of axonally transported and retinal proteins. Brain Res 200: 69-83.

OBLINGER MM, BRADY ST, MCQUARRIE IG, LASEK RJ (1987) Cytotypic differences in the protein composition of the axonally transported cytoskeleton in mammalian neurons. J Neurosci 7: 453-462.
OLINK-COUX M, HOLLENBECK PJ (1996) Localization and active transport of mRNA in axons of sympathetic neurons in culture. J Neurosci.16: 1346-58.

PALAY SL, SOTELO C, PETERS A, ORKAND PM (1968) The axon hillock and the initial segment. J Cell Biol 38: 193-201.

PANNESE E, LEDDA M (1991) Ribosomes in myelinated axons of the rabbit spinal ganglion neurons. J Submicrosc Cytol Pathol 23: 33-38.

PETERS A, PALAY S, WEBSTER HDEF (1991) Fine structure of the nervous system: neurons and their supporting cells. p 142. Oxford Press, New York.

PETERS A, PROSKAUER CC, KAISERMAN-ABRAMOF IR (1968) The small pyramidal neuron of the rat cerebral cortex. The axon hillock and initial segment. J Cell Biol 39: 604-619.

PIPER M, SALIH S, WEINL C, HOLT CE, HARRIS WA (2005) Endocytosisdependent desensitization and protein synthesis-dependent resensitization in retinal growth cone adaptation. Nat Neurosci 8: 179-186.

ROY S, COFFEE P, SMITH G, LIEM RK, BRADY ST, BLACKMM (2000) Neurofilaments are transported rapidly but intermittently in axons: implications for slow axonal transport. J Neurosci 20: 6849-6861.

SCHWARTZ JH, CAMILLI PD (2000) Synthesis and trafficking of neuronal proteins. In: KANDEL E, SCHWARTZ J, JESSELL T. Principles of neural science. 4th ed: New York, McGraw-Hill. pp: 88-104

SOTELO-SILVEIRA JR, CALLIARI A, KUN A, BENECH JC, SANGUINETTI C, CHALAR C, SOTELO JR (2000) Neurofilament mRNAs are present and translated in the normal and severed sciatic nerve. J Neurosci Res 62: 65-74.

SOTELO-SILVEIRA JR, CALLIARI A, CÁRDENAS M, KOENIG E, SOTELO JR (2004) Myosin Va and kinesin II motor proteins are concentrated in ribosomal domains (periaxoplasmic ribosomal plaques) of myelinated axons. J Neurobiol 60: 187-196.

SOTELO-SILVEIRA J, CRISPINO M, PUPPO A, SOTELO JR, KOENIG E (2008) Myelinated axons contain beta-actin mRNA and ZBP-1 in periaxoplasmic ribosomal plaques and depend on cyclic AMP and F-actin integrity for in vitro translation. J Neurochem. 104: 545-557

SOTELO-SILVEIRA JR, CALLIARI A, KUN A, KOENIG E, SOTELO JR (2006) RNA trafficking in axons. Traffic 7: 508-515.

TAYLOR AM, BERCHTOLD NC, PERREAU VM, TU CH, LI JEON N, COTMAN CW (2009) Axonal mRNA in uninjured and regenerating cortical mammalian axons. J Neurosci 29: 4697-4707.

TOTH CC, WILLIS D, TWISS JL, WALSH S, MARTÍNEZ JA, LIU W-Q, MIDHA R, ZOCHODNE DW (2009) Locally synthesized calcitonin generelated Peptide has a critical role in peripheral nerve regeneration. J Neuropathol Exp Neurol 68: 326-337.

VAN KESTEREN RE, CARTER C, DISSEL HM, VAN MINNEN J, GOUWENBERG Y, SYED NI, SPENCER GE, SMIT AB (2006) Local synthesis of actin-binding protein beta-thymosin regulates neurite outgrowth. J Neurosci 26: 152-157.

VERMA P, CHIERZI S, CODD AM, CAMPBELL DS, MEYER RL, HOLT CE FAWCETT JW (2005) Axonal protein synthesis and degradation are necessary for efficient growth cone regeneration. J Neurosci 25: 331-342.

VOGELAAR C, GERVASI N, GUMY L, STORY D, RAHA-CHOWDHURY R, LEUNG K, HOLT C, FAWCETT J (2009) Axonal mRNAs: Characterisation and role in the growth and regeneration of dorsal root ganglion axons and growth cones. Mol Cell Neurosci 42: 102-115.

VON BERNHARDI R, ÁLVAREZ J (1989) Is the supply of axoplasmic proteins a burden for the cell body? Morphometry of sensory nerurons and amino acid incorporation into their cell bodies. Brain Res 478: 301-308.

VUPPALANCHI D, WILLIS DE, TWISS JL (2009) Regulation of mRNA transport and translation in axons. Results Probl Cell Differ 48: 193-224.

WANG L, HO CL, SUN D, LIEM RK, BROWN A (2000) Rapid movement of axonal neurofilaments interrupted by prolonged pauses. Nat Cell Biol 2: $137-141$.

WEISS P, HISCOE HB (1948) Experiments on the mechanism of nerve growth. J Exp Zool 107: 315-395.

WEISS PA (1972) Neuronal dynamics and axonal flow. V. The semisolid state of the moving axonal column. Proc Natl Acad Sci USA 69: 620-623.

WENSLEY CH, STONE DM, BAKER H, KAUER JS, MARGOLIS FL, CHIKARAISHI DM (1995) Olfactory marker protein mRNA is found in axons of olfactory receptor neurons. J Neurosci 15: 4827-4837.

WILLARD M, COWAN WM, VAGELOS PR (1974) The polypeptide composition of intra-axonally transported proteins: evidence for four transport velocities. Proc Natl Acad Sci USA. 71: 2183-2187.

WILLIS D, LI KW, ZHENG J-Q, CHANG JH, SMIT A, KELLY T, MERIANDA TT, SYLVESTER J, VAN MINNEN J, TWISS JL (2005) Differential transport and local translation of cytoskeletal, injuryresponse, and neurodegeneration protein mRNAs in axons. J Neurosci 25: 778-791. 
WILLIS DE, VAN NIEKERK EA, SASAKI Y, MESNGON M, MERIANDA TT, WILLIAMS GG, KENDALL M, SMITH DS, BASSELL GJ, TWISS JL (2007) Extracellular stimuli specifically regulate localized levels of individual neuronal mRNAs. J Cell Biol 178: 965-980.

WU KY, HENGST U, COX LJ, MACOSKO EZ, JEROMIN A, UROUHART ER, JAFFREY SR (2005) Local translation of RhoA regulates growth cone collapse. Nature 436: 1020-1024.

YOO S, VAN NIEKERK EA, MERIANDA TT, TWISS JL (2010) Dynamics of axonal mRNA transport and implications for peripheral nerve regeneration.Exp Neurol 223: 19-27

YOON BC, ZIVRAJ KH, HOLT CE (2009) Local translation and mRNA trafficking in axon pathfinding. Results Probl Cell Differ 48: 269-288.
YUAN A, SASAKI T, RAO MV, KUMAR A, KANUMURI V, DUNLOP DS, LIEM RK, NIXON RA (2009) Neurofilaments form a highly stable stationary cytoskeleton after reaching a critical level in axons. J Neurosci 29: 11316-11329

ZELENÁ J (1972) Ribosomes in myelinated axons of dorsal root ganglia. Z Zellforsch Mikrosk Anat 124: 217-229.

ZHANG XH, POO M-M (2002) Localized synaptic potentiation by BDNF requires local protein synthesis in the developing axon. Neuron 36: 675688.

ZIVRAJ KH, TUNG YC, PIPER M, GUMY L, FAWCETT JW, YEO GS, HOLT CE (2010) Subcellular profiling reveals distinct and developmentally regulated repertoire of growth cone mRNAs. J Neurosci 30: 15464-15478. 
